\title{
STRATEGI ADAPTASI LINGKUNGAN, POLA EKONOMI, DAN PELESTARIAN KEKUASAAN, PAPARAN MENGENAI BEBERAPA DATA JAMAN INDONESIA KUNA
}

Oleh: Bugie Kusumohartono

Data arkeologis menunjukkan bahwa kelompok-kelompok masyarakat yang tersebar di kepulauan Nusantara telah berkembang sejak masa yang tua. Perkembangan tersebut tumbuh secara khas pada masing-masing kelompok sesuai dengan situasi lingkungan, karakteristik kelompok, maupun kondisi faktor-faktor yang mempengaruhinya. Sementara itu dimensi ruang dan waktu juga mempengaruhi model-model perubahan kebudayaan serta perkembangan masyarakatnya. Oleh sebab itu tidak mustahil sistem sosial dan budaya masyarakat di Nusantara pada saat yang bersamaan dapat menampilkan wujud yang majemuk.

Bambang Sumadio (ed., 1984:20) menegaskan bahwa salah satu perubahan nyata dalam masyarakat Indonesia, tampak berdasarkan tinggalan arkeologis abad V Masehi. Perubahan tersebut dilandasi oleh berbagai faktor, di antaranya adalah interaksi perdagangan dengan India dan Cina. Dengan kata lain, kontak perdagangan telah mendorong berlangsungnya akulturasi kebudayaan di kepulauan Nusantara (leur. 1967: 99). Walaupun demikian teori ini tidak sepenuhnya memberikan penjelasan mengapa budaya Cina tidak tampak pengaruhnya di Nusantara pada jaman Indonesia kuna awal. 
Wolters (1967:31) dan Leur (1967:90) pada dasarnya sependapat bahwa hubungan dagang dengan India berlangsung lebih awal dari pada dengan Cina. Minat India kepada komoditi dari Kepulauan Nusantara berawal dari kebutuhan mereka terhadap emas. Komoditi emas dari Kepulauan Nusantara menarik perhatian karena kawasan Asia Barat dan Laut Tengah, yang selama ini menyediakan emas bagi India, telah menutup kemungkinan tersebut karena alasan ekonomis. Sementara itu rute transportasi emas dari Siberia ke India telah tidak terjamin keamanannya (Coedès, 1968: 20).

Kepulauan Indonesia maupun Asia Tenggara pada umumnya terletak pada jalur transportasi perdagangan laut antara India dan Cina (Satyawati Sulaiman, 1984; Manguin, 1983). Pada awalnya, hubungan dengan Cina tidak sepenuhnya mengandalkan produk komoditi Nusantara. Holo-tan, misalnya, menghantarkan komoditi '...comprised a diamond ring, red parrots, with cloth from India, cloth from Gandhara, and such items. (Wolters, 1967: 78) ke Cina pada tahun 430 Masehi. Pada awalnya memang minat Cina terfokus pada komoditi Asia Barat dan India. Beberapa dari jenis-jenis komoditi tersebut adalah setanggi, batuperhiasan, mutiara, permata, gelas-kaca, dan tentu saja tekstil (Ibid: 41).

Walaupun hubungan dengan India telah berlangsung lebih awal. tetapi keterangan yang diperoleh mengenai hubungan dengan Cina lebih banyak diperoleh. Hal ini berkaitan dengan tradisi kearsipan Cina yang ketat sehingga menguntungkan bagi studi historiografi Cina dan kawasan-kawasan yang berhubungan. Keberhasilan kelompok-kelompok ma syarakat (kerajaan) di Nusantara berhubungan dengan Cina disebabkan karena kemampuannya menyiapkan komoditi yang menarik minat, teru tama bagi kelas elite politik. Menurut istilah Bambang Sumadio, '... ha ruslah berupa barang bernilai tinggi untuk konsumsi kalangan atas (198419). Dalam hal ini Kepulauan Nusantara menghasilkan produk komoditi yang memenuhi kriteria tersebut, di antaranya kemenyan. cendana, emas, perak, rempah-rempah, dan kapur barus (Ibid: 19-20)

Dalam berbagai literatur yang membahas tentang pola ekonomi pada jaman Indonesia kuna terdapat dualisme pemikiran yang belum 
menghasilkan garis singgung. Di satu pihak ditafsirkan berlangsungnya prosedur jual-beli melalui penerapan permintaan-penawaran di pasar (Wolters, 1967), di lain pihak digambarkan bahwa pola ekonomi di dalam kerajaan maupun ke luar kerajaan berlandaskan pada prosedur pertukaran komoditi (Leur, 1967). Merupakan suatu hal yang ironis bahwa pada berbagai kepustakaan yang lain kedua pola tersebut dirancukan dalam pembahasannya.

Pandangan yang menganut kepada adanya perdagangan 'pasar' menghasilkan pula implikasi khas mengenai pola hubungan politik dengan Cina. Kekuasaan-kekuasaan politik di Nusantara kerap kali dianggap sebagai 'taklukan' Cina yang pada kurun waktu tertentu mengirimkan misi dan upeti kepada penguasa Cina. Dengan demikian kearsipan Cina dianggap memberikan informasi mengenai negara-negara taklukan Cina, di antaranya kekuasaan politik di Nusantara, yang terikat dengan institusi upeti. Sebaliknya temuan mata uang Cina yang ada di Kepulauan Nusantara (Groeneveldt, 1960:47: Sukarto K. Atmodjo, 1979:65) dianggap sebagai indikasi berlangsungnya perdagangan secara intensif (Hasan M. Ambary, 1984: 5), dalam hal ini perdagangan 'pasar'.

II

Sebuah pendekatan 'baru tela'h diajukan oleh John N. Miksic (1981) sehubungan dengan pola ekonomi yang dipermasalahkan di atas. Pendekatan tersebut menekankan pehatiannya pada prosedur pertukaran (exchange) sebagai landasan dari pola ekonomi yang berlangsung. Dalam kajian tersebut, Miksic meletakkan aspek pertukaran di dalam suatu kerangka pemikiran di mana aspek strategi adaptasi lingkungan dan aspek pelestarian kekuasaan secara integrated berada di dalamnya.

Milssic (1981:1 - 5) melakukan ulasan terhadap pandangan Movius mengenai perkembangan teknologi prasejarah di Indonesia. Pada awalnya Movius meragukan adanya kemajuan, baik dalam hal variasi maupun teknik, pada hasil teknologi di kawasan Indonesia. Pandangan ini, menu- 
rut Miksic, disebabkan karena Movius tidak memberikan perhatian pada aspek strategi adaptasi lingkungan maupun aspek pola penyebaran artefak.

Strategi adaptasi lingkungan melahirkan perkembangan teknologi walaupun tidak selalu dapat diamati secara tegas. Kawasan Nusantara yang berhutan tropik hujan dan muson (Ripley, 1979) melahirkan index keanekaragaman (diversity index) yang tinggi (Geertz, 1976:1-50). Menurut Miksic, alat-alat batu pada lingkungan semacam itu lebih berfungsi sebagai alat produksi untuk menciptakan beragam alat lain yang terbuat dari bahan kayu, bambu, dan tulang-tanduk, dari pada berfungsi sebagai senjata untuk berburu dan meramu. Dengan demikian tidak mustahil didapatkan data artefak batu yang memiliki variasi serta bentuk yang relatif tidak berubah pada kurun waktu yang relatif panjang.

Selain faktor strategi adaptasi lingkungan, Miksic menunjuk bahwa pola penyebaran artefak merupakan data yang penting untuk melihat sebab 'kemandekan' pada perkembangan teknologi. Pola penyebaran artefak berkaitan erat dengan kegiatan pertukaran yang berlangsung di antara dua situs atau lebih. Dengan demikian perubahan pada pola penyebaran yang teramati dapat memperlihatkan adanya adaptasi kebudayaan yang baru yang sulit diamati oleh pendekatan teknologis semata.

Berdasarkan studi etnografi, Miksic (1981:5-6) melihat bahwa pertukaran secara adat merupakan tradisi yang panjang terutama pada bangsa-bangsa Austronesia. Tradisi pertukaran tersebut terutama berlangsung di antara dua kelompok atau lebih yang memiliki perbedaan relung ekologi. Sebagai contoh dikemukakan mengenai pertukaran antara kelompok manusia pengumpul hasil hutan di pedalaman dengan kelompok manusia yang menyediakan produk dari pesisir di Semenanjung Melayu. Hal yang serupa ditunjukkan pula oleh Miksic berlangsung di Pulau Luzon, Kepulauan Trobriand-Melanisia, Irian, Kepulauan Admiralty, Kepulauan Bismarck, Australia, dan Selandia Baru. Pada periode pemerintahan Anak Wungsu di Bali, terdapat sekelompok individu yang menyelenggarakan pertukaran kebutuhan hidup di antara masyarakat yang tinggal di pedalaman dengan masyarakat yang tinggal di pesisir utara Pulau Bali (Sukarto K. Atmodjo, 1979:68). 
Pada sumber-sumber sejarah, Miksic (1981:7-8) juga menjumpai tradisi pertukaran semacam itu. Kegiatan perdagangan sejak awal abad Masehi di Nusantara berlangsung pada tempat-tempat tertentu atau bandar. Prosedur yang berlaku tidak jerdasarkan atas permintaan-penawaran melainkan atas dasar persett uan politik. Menyinggung kepada hubungan pengiriman misi pelayari $n$ dan komoditi ke Cina oleh penguasapenguasa politik Nusantară, Miksic menyatakan '... bahwa prosedur ini hanya merupakan alasan untu!: m nukar bahan: rempah, damar dan hasil hutan dari Indonesia; (dengan) kai s sutera, logam dan keramik dari Cina...' Dalam prosedur ini perhitungan rugi-laba tidak dinilai secara komersial tetapi harus dipahami dengan pendekatan sosioekonomis.

Kegiatan pertukaran tersebut tidak terbatas berlangsung di antara kelas elite politik Nusantara dar. Cina tetapi melibatkan pula kalangan 'swasta'. Pertukaran yang meliba' taan kalangan swasta tersebut tetap didasarkan atas a dat dan bukan p: ssedur permintaan-penawararı. Pendapat Miksic tersebut senada dengan Leur (1967). Leur menegaskan bah. wa kelas elite politik di Kepulauan: Nusantara memainkan peranan yangु dominan dalarn kegiatan ekonoirit. Kelas tersebut pada umumnya memiliki faktor-faktor produksi, misalr:ya kapal, modal, serta anak kapalnya. Mereka juga turut menentukan aturan adat untuk memutuskan nilai komoditi yang dipertukarkan, mendapat prioritas untuk melaksanakan pertukaran terlebih dahulu, maurun menentukan bea pelabuhan. Keterlibatan swasta dalam kegiatar ek..nomi, bagaimanapun juga, tunduk kepada aturan-aturan yang dirumı:skan oleh kelas elite penguasa (Ibid $66-67)$.

Leur melihát bahwa sistem pertukaran adat yang berlangsung di antara masyarakat kepulauaan Melanesia, Kula, merupakan gambaran yang menjelaskan pola ekonomi pada kelompok-kelompok masyarakat dengan lapisan sosial atas yarig 'aristokratik' maupun pada struktur sosial yang bersifat 'republik' (Ibid: 54-56).

Latar belakang dari pola ekonomi semacam itu menurut Miksic adalah '...bukan untuk mengumpulkan harta, tetapi untuk mendekati tujuan politik'. Secara singkat dapat dirumuskan bahwa kekayaan, termasuk di 
dalamnya pemilikan lambang-lambang status yang langka maupun kemampuan untuk menyalurkan energi kepada anggota masyarakat yang lain, merupakan syarat untuk mencapai status yang tinggi dalam masyarakat. Sehingga apabila seorang penguasa telah mampu menyalurkan bahan sebagai kewajiban kepada warga masyarakat yang lain, maka anggota masyarakat tersebut terikat dengan kewajiban-kewajiban terhadap penguasa. Yang berlangsung di sini adalah proses pertukaran energi dan pelestarian keseimbangan di antara komponen-komponen dalam suatu organisasi kemasyarakatan (Geertz, 1976).

Pola ekonomi yang diajukan oleh Miksic tersebut apabila dijabarkan dalam wujud bagan prosedur pertukaran jaman Indonesiakuna, menampakkan suatu sistem redistribusi (1981: $11-12)$.

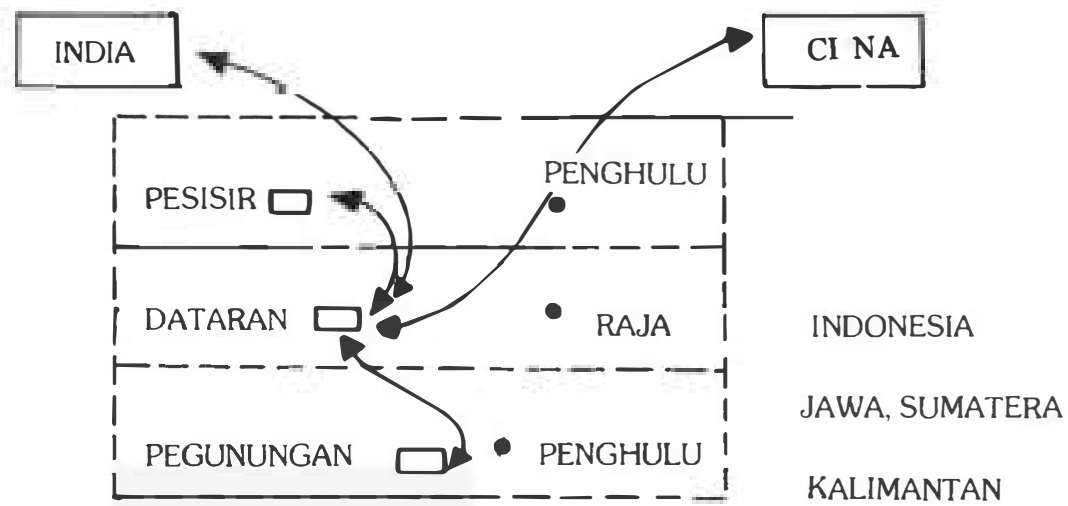

Dalam kaitan ini dipandang perlu untuk mencoba memaparkan data dari jaman Indonesia kuna guna menguji, walaupun dalam tahap yang awal, relevansi kerangka pemikiran Miksic tersebut dengan kenyataan yang berlaku di Kepulauan Nusantara. Mengingat data sosioekonomi yang terbanyak dijumpai berasal dari sekitar abad XIII - XV (Sri Soejatmi Satari, 1984) maka pembahasan di bawah ini akan banyak mengacu pada masa-masa tersebut, khususnya periode Majapahit. Selain itu diusahakan pula pengungkapan data yang berasal dari masa-masa sebelumnya yang sejaman. 
Nêgarakêrtăgama pupuh 82 bait pertama memberikan keterangan mengenai adanya kewajiban penguasa kepada rakyatnya, yang secara khusus disebut sebagai dharma. Dalam hubungan penguasa dan kelas sosial di bawahnya, dharma dijabarkan juga sebagai anugerah. Anugerah tersebut diturunkan kepada aparat pemerintahan bawahan raja serta terutama kepada masyarakat jelata/desa (Boechari, 1981:78).

Prasasti-prasasti dari periode Sindok dan Airlangga baryak memberikan informasi mengenai perhatian besar penguasa kepada pertanian rakyat. Hasil fisik dari perhatian tersebut diwujudkan dalam bentuk pembangunan serta pembinaan prasarana pertanian, khususnya perangkat tekno-hidrologi (Meer, 1979:xviii dan 23). Kondisi semacam ini berlangsung terus sampai dengan periode Majapahit, bahkan dalam intensitas yang lebih tinggi (Ibid: 134; Nāgarakērtāgama pupuh 88). Mengingat penanganan prasarana fisik tersebut membutuhkan padat karya maka dapat disimpulkan bahwa kekuasaan politik dari penguasa mampu untuk menggalang motivasi dan tenaga rakyat bagi pembangunan tersebut. Tanpa adanya political will dari pihak penguasa maka upaya semacam itu sulit untuk diwujudkan.

Anugerah penguasa kepacla rakyat juga meliputi berbagai bentuk jaminan sosial. Yang dimaksud dengan jaminan sosial antara lain berupa penyelenggaraan pertahanan keamanan bagi rakyat, penyelenggaraan tertib hukum, pelayanan menghadapi bencana alam, pelayanan bagi masyarakat dalam menghadapi wabah penyakit, pelayanan dalam menghadapi hama tanaman, yang semuanya diselenggarakan oleh berbagai kelembagaan di dalam birokrasi pemerintahan (Casparis, 1983:8; Nâgarakērtāgama pupuh $88-89$ ).

Anugerah penguasa disalurkan pula kepada kalangan lembaga-lembaga keagamaan. Dalam Negarakertagama pupuh 82 bait kedua dan ketiga diperoleh gambaran mengenai perhatian penguasa kepada pembangunan dan pemeliharaan bangunan-bangunan pemujaan, biara, maupun perdikan yang berfungsi bagi kepentingan keagamaan. Dari jaman 
Indonesia kuna awal diperoleh data yang sangat relevan dari kekuasaan politik di Kutai, Kalimantan Timur. Kepada para Brahmana di lingkungan kerajaan, Mulawarman memberikan anugerah berupa emas, tanah (perdikan?), minyak, lampu, malai bunga (madu?), dan 20.000 (?) ekor sapi (Bambang Sumadio, 1984:31 - 33). Nampaknya bahan-bahan tersebut mempunyai nilai tinggi dan bahkan langka didapatkan di Kutai pada masa itu.

Jenis anugerah lain yang dapat diungkapkan adalah kegiatan pesta atau perayaan. Memang kegiatan tersebut memiliki fungsi tersendiri dan khusus,tetapi di pihak lain dapat teramati proses penyaluran energi dari penguasa kepada rakyat. Nāgarakērtágama mencatat paling tidak dua kegiatan pesta-perayaan yang diselenggarakan dalam pemerintahan Hayam Wuruk, yaitu pesta Sraddha dan perayaan bulan Caitra (pupuh $65-66$ dan 87 -90). Dalam kedua perayaan tersebut dihidangkan berjenis-jenis makanan dalam jumlah yang banyak. Hidangan tersebut dianugerahkan bagi tamu yang hadir. Anugerah semacam ini bersifat lebih khusus karena hanya diikuti secara terbatas oleh undangan saja. Selain itu diselenggarakan pula berbagai jenis hiburan sebagai anugerah santapan mata bagi masyarakat luas.

Selain menyalurkan energi (anugerah) kepada rakyat, penguasa menuntut penerimaan yang kurang lebih seimbang dari rakyat. Sumber utama pemasukan bagi penguasa pada jaman Indonesia kuna adalah berasal dari pajak. Menurut Boechari (1981:67), sumber penerimaan tersebut meliputi pajak tanah/hasil bumi, pajak perdagangan/penjualan, dan pajak atas hasil kerajinan. Selain itu diterima pula oleh penguasa penerimaan berupa denda sanksi hukum serta penyerahan tenaga rakyat (gawai/buat haji). Pentingnya pajak bagi penguasa didapatkan datanya dalam Nagarakertagama pupuh 88 bait keenam.

Penerimaan pajak bagi penguasa dan para elite politik berbentuk dua macam alat pembayaran. Pajak hasil bumi, pajak penjualan, pajak hasil kerajinan, serta denda dapat dibayarkan secara in natura (ibid: $69-$ 70; Edhie Wuryantoro, 1982). Selain secara in natura, pajak, denda, dan gawai dapat dibayar dengan alat tukar yang berlaku (Ibid). 
Sebagaimana diuraikan di depan, hasil bumi, ternak, dan komoditi kerajinan merupakan potensi perdagangan yang penting (supra). Dengan demikian nampaknya penerimaan kas penguasa secara in natura, terutama hasil bumi, lebih diutamakan. Hal ini selaras dengan pandangan Burger (1960: 31 - 39) yang berpendapat bahwa hasil pertanian surplus merupakan sandaran kehidupan politik kelasyang berkuasa. Hasil panen dua kali setahun di persawahan Jawa abad XIV - XV Masehi (Groeneveldt, 1960:48) merupakan bukti tingginya produktivitas pertanian masa itu.

Kalangan elite politik kerajaan memiliki kepentingan kuat terhadap sumber-sumber penerimaan dari surplus hasil bumi. Untuk berlangsungnya penerimaan yang mantap maka diciptakan mekanisme sedemikian rupa pada sistem sosial-politik di dalam wilayah kerajaan.Casparis (1983) melihat bahwa proses pemusatan otoritas politik kepada pihak penguasa telah berlangsung antara abad X sampai dengan XV Masehi. Dengan semakin tersentralisasikannya kekuasaan politik ke tangan penguasa maka penyelenggaraan pajak melalui aparat pemerintahan di pedesaan (Boechari, 1981:72) berlangsung lebih efektif.

Penyaluran energi dari penguasa kepada rakyat, dalam hal ini anugerah, diimbangi oleh rakyat dalam wujud pajak dan denda, khususnya secara in natura. Dalam hal ini terlihat bahwa suatu prosedur pertukaran telah berlangsung di antara penguasa dan rakyat. Di lain pihak, pemasukan yang diterima oleh penguasa, misalnya padi, ternak dan barang kerajinan, merupakan komoditi yang mendapatkan minat besar dari wilayah-wilayah lain di luar Jawa, yang memiliki keterbatasan ekologi untuk menghasilkan produk komoditi yang serupa.

Sebagai contoh akan ditampilkan di sini beberapa ilustrasi mengenai kaitan antara lokasi dengan produk-produk tertentu yang dihasilkannya. Pulau Sumatra, misalnya, kurang sesuai bagi pertanian padi sawah karena sebagian besar dataran rendahnya merupakan hutan rawa gambut (Jazanul Anwar, et. al., 1984). Ekosistem Pulau Sumatra, Kalimantan dan Irian memiliki lebih banyak kemiripan dibandingkan dengan Jawa, Sulawesi, atau Nusa Tenggara. Ketiga pulau yang disebut di muka me- 
miliki potensi sebagai penghasil hutan. Sedangkan vegetasi pada tiga pulau yang disebut terakhir lebih didominasi oleh tanaman non keras.

Selain vegetasi, kekhasan ekosistem masing-masing pulau di Nusantara ditampakkan pula pada hasil tambangnya. Emas-perak, misalnya, banyak didapatkan di Pulau Sumatra. Intan hampir didapatkan hanya di Kalimantan. Sedangkan garam batu hanya dijumpai di Madura dan Pulau Kei, demikian seterusnya (Bachrawi Sanusi, 1984).

Memperhatikan kekhususan produk komoditi tiap pulau maka dapat ditafsirkan bahwa berbagai kekuasaan politik di Kepulauan Nusantara telah saling berhubungan sejak jaman yang tua. Hubungan tersebut bahkan juga berlangsung dengan kawasan lain di luar Nusantara. Kerajaan Majapahit, misalnya, telah mampu mengembangkan pola perekonomiannya. Mekanisme yang mantap berhasil menarik kedatangan misi utusan serta pedagang dari berbagai kawasan, di antaranya adalah Jambudwipa, Kamboja, Cina, Yamana, Campa, Karnataka, Goda, dan Siam (Nagarakertagama pupuh 83 bait keempat).

Dalam Nagarakertagama pupuh 85 bait kelima disebutkan bahwa upeti datang juga dari utusan luar Jawa (Nusantara). Institusi upeti nampaknya merupakan prosedur yang berlaku bagi para misi dan pedagang asing. Mengingat banyaknya jumlah wilayah yang berhubungan dengan Majapahit maka dapat dibayangkan seberapa banyak jumlah yang diterima oleh penguasa Majapahit berupa berbagai komoditi yang pada umumnya hanya dihasilkan di luar Jawa.

Dari uraian di atas nampak jelas bahwa penguasa melakukan kontak langsung dengan pedagang maupun misi dari luar wilayahnya. Pola hubungan tersebut tidak bersandar pada motif ekonomi melainkan politik. Dengan kata lain, aturan permainan yang melandasi prosedur berpindahnya komoditi dari satu tangan ke tangan yang lain dan sebaliknya lebih merupakan suatu kebijakan politik.

Bambang Sumadio (1981:18) dengan tegas menyebut perdagangan dengan Cina pada jaman Indonsia kuna adalah suatu hubungan politik. Hubungan semacam ini jelas melibatkan kalangan elite politik, 
bahkan para penguasanya (Ibid: 21). Dengan demikian menjadi jelas, mengapa arsip-arsip Cina selalu menyebutkan asal wilayah kekuasaan politik dari misi atau pedagang yang berhubungan dengan Cina. Pedagang atau pelayar tersebut pada dasarnya tidak. lain adalah misi yang bertugas mendapatkan komoditi asing melalui prosedur pertukaran dengan penguasa politik setempat. Komoditi tersebut merupakan lambang status yang tinggi nilainya bagi pemilik yang baru. Apabila komoditi tersebut disalurkan kepada warga masyarakat yang lain maka status penerima akan lebih rendah dan bahkan diikat dengan kewajiban kepada pihak pemberi.

Berlakunya prosedur barter pada jaman Indonesia kuna dibuktikan pula dengan tidak dijumpainya alat-alat tukar (mata uang) negara lain selain cina di Indonesia (Sukarto K. Atmodjo, 1979:65; Sri Soejatmi Satari, 1984:5). Nampaknya mata uang tidak berlaku bagi kegiatan perdagangan karena yang berlangsung adalah prosedur pertukaran. Sementara itu kepeng Cina yang banyak dijumpai di situs-situs arkeologi Indonesia dipandang sebagai komoditi pertukaran pula. Dengan kata lain kepeng Cina tersebut dinilai secara intrinsik dan bukan nominal.

Sebagai analogi dari tafsiran di atas akan dilihat bersama pola serupa yang sampai dengan dua atau tiga dekade yang lalu berlangsung di pedalaman Irian Jaya. Masyarakat pedalaman Irian Jaya pada waktu itu masih lebih menganggap berharga uang kertas dengan nilai pecahan Rp.100, - (warna merah) dari pada uang kertas dengan nilai pecahan lebih besar (warna tidak merah). Hal ini disebabkan karena warna merah memiliki arti tersendiri yang berkaitan dengan lambang-lambang status tinggi di dalam masyarakat. Sampai dengan saat ini pun masyarakat pedalaman Irian Jaya lebih suka menerima uang kertas dari pada uang logam walaupun bernilai sama.

\section{IV}

Paparan beberapa data di atas membuahkan penafsiran bahwa pola ekonomi di Nusantara pada jaman Indonesia kuna memberlakukan prosedur pertukaran di dalam kegiatan perdagangan. Penguasa politik ber- 
fungsi menjembatani lokalitas-lokalitas yang memiliki perbedaan potensi komoditi akibat perbedaan relung ekologi. Di antara penguasa dan lokalitas-lokalitas tersebut berlangsung suatu proses redistribusi energi. Penyaluran energi dari penguasa kepada misi asing, pedagang, dan rakyat berwujud anugerah, baik fisik maupun non fisik. Sebaliknya penyaluran energi dari misi asing dan pedagang diwujudkan sebagai upeti atau persembahan. Sedangkan dari rakyat berlangsung penyaluran bahan kepada pihak kelas penguasa dalam wujud pajak, denda, dan iuran tenaga.

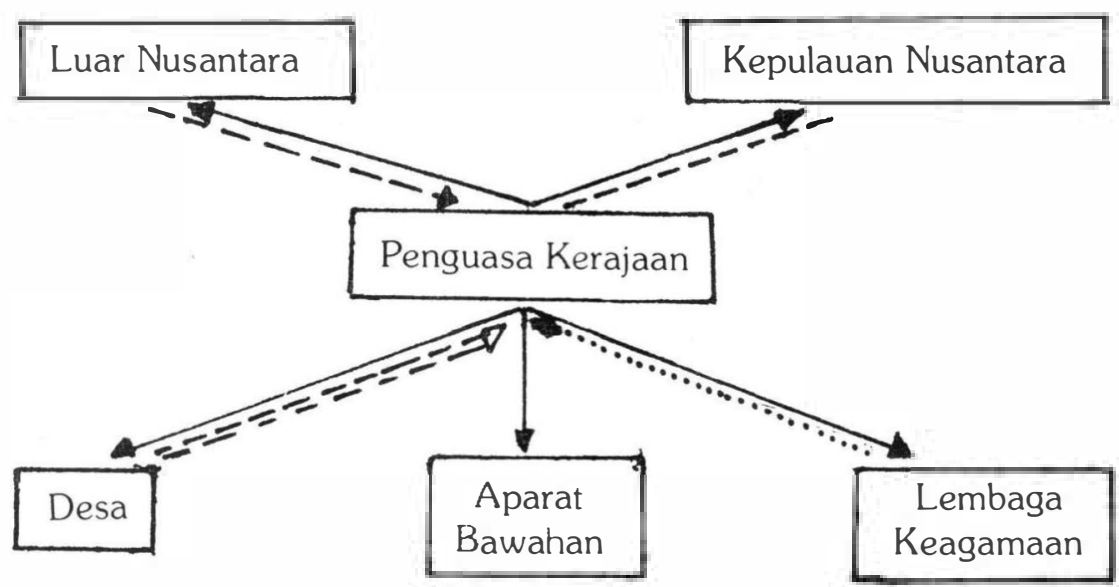

Keterangan:

anugerah/hadiah

-... upeti/persembahan

- - - pajak/denda/iuran tenaga

loyalitas/tenaga

dukungan moril/abhiseka 
Mekanisme redistribusi energi merupakan social glue yang mengikat berbagai kepentingan ekonomi dan politik di antara warga masyarakat, termasuk di dalamnya kelas yang berkuasa. Social glue dilandasi oleh adanya spesialisasi di antara warga masyarakat (Coe, 1961:6566). Social glue juga berfungsi melestarikan keseimbangan di dalam masyarakat dan dengan demikian merupakan sarana efektif guna melestarikan kekuasaan yang dimiliki oleh kelas elite politik. Sedikit saja berlangsung ketidakseimbangan dalam mekanisme ini, maka seluruh sistem yang telah dibangun melalui kurun yang panjang akan melemah sedikit demi sedikit menuju kehancuran.

Pada akhirnya perlu ditinjau kembali pernyataan yang secara sepihak menganggap terdapat ketimpangan dalam kehidupan sosioekonomi pada masyarakat Indonesia kuna. bagi keuntungan kelas elite politik (Machi Suhadi, 1984: 3 dan seterusnya). Ketimpangan semacam itu bagaimanapun juga disadari oleh kelas elite politik yang berkuasa. Ketimpangan sosioekonomis dapat menimbulkan gangguan yang mengancam stabili. tas kekuasaan politik yang berlangsung. Hanya saja kita masih menunggu lagi data-data arkeologis yang lebih kaya guna mengungkapkan masalah ini. Untuk itu lebih tepat seandainya penelitian lapangan dapat diarahkan kepada pemukiman-pemukiman yang bertaraf desa. Dari sana akan dapat diperoleh data-data yang lebih relevan bagi upaya penompakungkapan keadaan sosioekonomi. khususnya pada masyarakat Indonesia kuna. 


\section{RUJUKAN}

Bachrawi Sanusi. 1984. Mengenal Hasil Tambang Indonesia. Jakarta: Bina Aksara.

Bambang Sumadio (ed.). 1984. Sejarah Nasional Indonesia, II. Jakarta: Balai Pustaka.

Boechari. 1981. "Ulah Para Pemungut Pajak di dalam Masyarakat Jawa Kuna", Majalah Arkeologi, IV/ 1 - 2. Lembaga Arkeologi FSUI, Halaman 67 - 87.

Burger, D.H. 1960. Sejarah Ekonomis Sosiologis Indonesia, I. Djakarta: Pradnja Paramita.

Casparis, J.G. de. 1983. Evolution of the Socio-Economic Status of the East Javanese Village and Its Inhabitants, c. A.D. 900-1400. The Fourth Indonesian Dutch History Conference.

Coe, Michael D. 1961. "Social Typology and the Tropical Forest Civilization", $\mathrm{CSSH}, 4 / 1$. halaman $65-85$.

Coedes, G. 1968. The Indianized States of Southeast Asia. Kuala Lumpur Singapore: University Malay Press.

Edhie Wuryantoro. 1982. "Pajak dalam Abad Kesebelas dan Keduabelas". MISI, XI/01. FSUI, halaman $73-80$.

Geertz, Clifford. 1976. Involusi Pertanian: Proses Perubahan Ekologi di Indonesia. Jakarta: Bhratara KA.

Groeneveldt, W.P. 1960. Historical Notes on Indonesian and Malaya Compiled from Chinese Sources. Djakarta: Bhratara.

Hasan M. Ambary. 1984. Archaeological Research in Indonesia Related to Commodity Products and Maritime trade. SPAFA Consultative Workshop on Research On Maritime Shipping and Trades Networks in Southeast Asia.

Jazanul Anwar (et.al.). 1984. Ekologi Ekosistem Sumatera. Gadjah Mada University Press. 
Leur, J.C. van. 1967. Indonesian Trade and Society. The Hague - W. van Hoeve.

Machi Suhadi. 1967. Beberapa Jenis Pajak pada Jaman Majapahit. Rapat Evaluasi Hasil Penelitian Arkeologi, II.

Manguin, Pierre - Yves. "Dunia yang Ramai: Laut Cina dengan Jaringan-jaringannya" Citra Masyarakat Indonesia. Sinar Harapan, Halaman 83 - 96.

Meer, N.C. van Setten van der. 1979. Sawah Cultivation in Ancient Java. Canbera: ANU Press.

Miksic, John N. 1981. "Perkembangan Teknologi, Pola Ekonomi dan Penafsiran Data Arkeologi di Indonesia", Majalah Arkeologi, IV/ 1 - 2. Lembaga Arkeologi FSUI, Halaman 1 - 16.

Pigeaud, Th. 1960 - 1963. Java in the Fourteenth Century, I V. The Hague Martinus Nijhoff.

Ripley, S. Dillon. 1979. Alam dan Margasatwa Asia Tropik. Jakarta: Tira Pustaka.

Satyawati Suleiman. 1984. Maritime Routes in the Classical Period. SPAFA Consultative Workshop on Research on Maritime Shipping and Trades Networks in Southeast Asia.

Slamet Mulyono. 1979. Nagarakertagama dan Tafsir Sejarahnya. Jakarta: Bhratara KA

Sri Soejatmi Satari. 1984. Kehidupan Ekonomi di Jawa Timur dalam Abad XIII-XV. Rapat Evaluasi Hasil Penelitian Arkeologi, II.

Sukarto K. Atmojo, M.M. Struktur Masyarakat Jawa Kuno pada Jaman 1879 Mataram Hindu dan Majapahit Yogyakarta: PPSK UGM.

Wolters, O.W. 1967. Early Indonesia Commerce. Ithaca:

Cornell University Press. 